African Crop Science Journal by African Crop Science Society is licensed under a Creative Commons Attribution 3.0 Uganda License. Based on a work at www.ajol.info/ and www.bioline.org.br/cs DOI: https://dx.doi.org/10.4314/acsj.v28i4.6

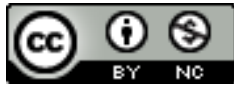

\title{
MORPHOLOGICAL AND MOLECULAR CHARACTERISATION OF Streptomyces spp. WHICH SUPPRESS PATHOGENIC FUNGI
}

\author{
N. GOREDEMA, T. NDOWORA, R. SHOKO and E. NGADZE ${ }^{1}$
}

Chinhoyi University of Technology, Private Bag 7724, Chinhoyi, Zimbabwe

${ }^{1}$ University of Zimbabwe, P. O. Box MP 167 Mt. Pleasant, Harare, Zimbabwe

Corresponding author: nyashaemma@gmail.com

(Received 26 September 2019; accepted 2 October 2020)

\begin{abstract}
Streptomyces species are aerobes and chemoorganotrophic bacteria. These microorganisms produce a wide range of industrially significant compounds, specifically antibiotics and anti fungal substances. The objective of this study was to characterise soil-borne Streptomyces isolates using morphological and molecular traits in order to identify them to species level, and leverage from their potential to suppress the growth of Aspergillus flavus, Fusarium oxysporum and Penicillium italicum. Twentyseven soil-borne putative Streptomyces, which elicited comprehensive antimicrobial activity against Aspergillus flavus, Fusarium oxysporum and Penicillium italicum, in a previous study, were evaluated. On the basis of morphology, the bacteria resembled the genus Streptomyces. Initially, colonies phenotypically appeared to have a relatively smooth surface but as growth progressed the bacteria developed a weft of aerial mycelium granular, powdery or velvety in appearance. Bacteria produced a wide variety of pigments which in turn were responsible for the colour of the vegetative and aerial mycelia, colour ranged from white to cream or buff shades and yellow to orange or brown. Microscopic analyses and morphological characteristics generated sub-groups of the isolates and clustered them according to their similarities. One bacterial strain was randomly selected from each cluster and investigated using molecular characteristics. Partial 16S rDNAs from the selected representative isolates from each subgroup, were sequenced and phylogenetic analysis performed. The 16S rDNA sequences of the isolates indicated that they were related to Streptomyces species: S. bungoensis, $S$. thermocarboxydus, $S$. corchorusii and $S$. lasaliensis, that are known secondary metabolite producers possessing antimicrobial activity against plant pathogens.
\end{abstract}

Key Words: Antimicrobial activity, phylogenetic analysis, secondary metabolites

\section{RÉSUMÉ}

Les espèces de Streptomyces sont des bactéries aérobies et chimio-organotrophes. Ces microorganismes produisent une large gamme de composés d'importance industrielle, en particulier des antibiotiques et des substances antifongiques. L'objectif de cette étude était de caractériser les isolats de Streptomyces transmis par le sol à l'aide de traits morphologiques et moléculaires afin de les 
identifier au niveau de l'espèce, et de tirer parti de leur potentiel à supprimer la croissance d'Aspergillus flavus, Fusarium oxysporum et Penicillium italicum. Vingt-sept Streptomyces putatifs transmis par le sol, qui ont suscité une activité antimicrobienne complète contre Aspergillus flavus, Fusarium oxysporum et Penicillium italicum, dans une étude précédente, ont été évalués. Sur la base de la morphologie, les bactéries ressemblaient au genre Streptomyces. Au départ, les colonies semblaient phénotypiquement avoir une surface relativement lisse, mais au fur et à mesure que la croissance progressait, les bactéries développaient une trame de mycélium aérien d'aspect granuleux, poudreux ou velouté. Les bactéries produisaient une grande variété de pigments qui à leur tour étaient responsables de la couleur des mycéliums végétatifs et aériens, la couleur variait du blanc au crème ou au chamois et du jaune à l'orange ou au brun. Des analyses microscopiques et des caractéristiques morphologiques ont généré des sous-groupes d'isolats et les ont regroupés en fonction de leurs similitudes. Une souche bactérienne a été sélectionnée au hasard dans chaque groupe et étudiée en utilisant des caractéristiques moléculaires. Des ADNr 16S partiels provenant des isolats représentatifs sélectionnés de chaque sous-groupe ont été séquencés et une analyse phylogénétique a été effectuée. Les séquences d'ADNr $16 \mathrm{~S}$ des isolats ont indiqué qu'ils étaient apparentés aux espèces de Streptomyces: S. bungoensis, S. thermocarboxydus, S. corchorusii et S. lasaliensis, qui sont des producteurs de métabolites secondaires connus possédant une activité antimicrobienne contre les phytopathogènes.

Mots Clés: activité antimicrobienne, analyse phylogénétique, métabolites secondaires

\section{INTRODUCTION}

Streptomyces, previously termed Actinomyces, was discovered by Waksman and Henrici (1943). These were later extensively studied and found to be spore-forming, Gram-positive bacteria with a filamentous form (Compant $e t$ al., 2005). Streptomyces is a genus of over 500 species of Gram-positive bacteria in the phylum Actinobacteria, order Streptomycetales and family Streptomycetaceae. Phylum Actinobacteria to which Streptomyces belong is one of the largest taxonomic units among all the 18 major lineages of studied bacteria (Ludwig, 2012). Over time, the taxonomy of Actinobacteria has evolved significantly as more bacteria are being studied. The order in which Streptomyces belong, Actinomycetales, was established in 1917 by Buchanan.

Streptomyces species are aerobes and chemoorganotrophic bacteria. These microorganisms produce a wide range of industrially significant compounds, specifically antibiotics and anti-fungal substances (Berdy, 2012; Compant et al., 2016). Their genomes have a high GC content of about 70-78\% (Kavitha et al., 2010). Streptomyces have very small filaments and spores, which usually have a diameter of $1 \mu \mathrm{m}$ or less (Willemse et al., 2011). Streptomyces colonies are slow-growing and in most cases, they release a soil-like odour attributed to the production of geosmin a volatile metabolite (Jüttner and Watson, 2007). Initially, Streptomyces colonies phenotypically appear to have a relatively smooth surface, but as growth progresses, they develop a weft of aerial mycelium visually different, and may be granular, powdery or velvety in appearance (Ambarwati et al., 2012).

Streptomyces are ubiquitous in soil habitats and aquatic sediments (Gontang et al., 2007). They are widely distributed and abundant in soil, predominantly in composts and decaying vegetation.

Streptomycetes are also capable of degrading cellulose, lignocellulose, chitin and many other organic compounds in biogeochemical cycles (Lewin et al., 2012). Streptomyces degrade adenine, casein, esculin, gelatin, hypoxanthine, starch, and ltyrosine (Smaoui et al., 2011). They also are catalase positive and have the ability to reduce nitrates to nitrites (Smaoui, et al., 2011). Within the temperature range of $25-35^{\circ} \mathrm{C}$ and a $\mathrm{pH}$ in 
the neutral range 6.5 - 8 Streptomyces grow best. They occur in the same habitats as fungi (Ikeda et al., 2003).

Streptomyces produce a variety of pigments, which in turn are responsible for the colour of the vegetative and aerial mycelial appearance (Flärdh et al., 2009). Their colour ranges from white to cream or buff shades; yellow to orange or brown; pink to cinnamon, red or pinkish tan to lavender; and green to grey or blue.

A wide range of organic compounds are available as carbon sources for Streptomyces energy and growth.

Developing zero-chemical master-plans for the control of plant pathogens is one of the major issues that have caught global attention in recent years.

Unfortunately, only a few attempts have been done so far on morphological and molecular characterisation of Streptomyces. The objective of this study was to characterise soil-borne Streptomyces spp. isolates, morphological and molecular, to identify them and to leverage from their potential to suppress the growth of Aspergillus flavus, Fusarium oxysporum and Penicillium italicum.

\section{METHODOLOGY}

Streptomyces strains. Twenty-seven Streptomyces spp. isolates, collected from Chinhoyi University of Technology Farm soils (Goredema et al., 2020), were examined for their growth characteristics and morphology in agar media.

Morphological characterisation. For the characterisation, Streptomyces isolates were grown in OA amended with cycloheximide (50 $\mu \mathrm{l} / \mathrm{ml}$ ), then incubated at $28{ }^{\circ} \mathrm{C}$ for 3 days. The variables that were assessed at day 14 in culture were growth rate, mycelium colour, mycelia surface appearance, mycelia texture, pigmentation, opacity, spore shape and spore colour (Davelos et al., 2004).

The morphological traits that were assessed were grouped into categories and each category was given a number from 0-5 depending on the number of sub categories within a specific group. The growth rates of Streptomyces isolates were determined by measuring their radii on the agar plate, relative to each other. There were three Streptomyces isolates with growth rate categories with the largest diameters which were ranked as fast growers; while those with the least growth were ranked as slow growers. Growth rate categories were assigned number from 0-2 from the slowest growers to the fastest growers.

Mycelia colour of Streptomyces isolates growing on Oatmeal Agar (OA), was assessed visually and the four colour categories were yellow to orange, brown, greenish to grey, and white to cream, with each colour category assigned a number from 0-3, respectively.

Mycelia texture was also visually assessed and classified into three categories, which were mucoid, viscid or buttery. Streptomyces spp. pigmentation was grouped into four categories which were colourless, white, brown and yellow. Opacity (visible light impenetrability) was categorised as opaque or translucent. (Davelos et al., 2004).

Surface appearance of the Streptomyces isolates was classified into three categories, namely smooth, rough or glistering. Spore shapes as observed under a light microscope (Leica dm500) at a magnification of 100x and 400x, were classified as either globose or rod shaped. Colours of spores were classified in four groups, namely white, grey, brown and yellow as described by Davelos et al. (2004).

Statistical data analysis. Data were subjected to cluster analysis using Minitab software for windows version 16.1. Variable comparison was performed using Correlation Coefficient Distance and Average Linkage amalgamation steps.

Molecular characterisation. For the molecular characterisation, selected Streptomyces isolates were grown on oatmeal agar (OA) amended with cycloheximide (50 
$\mu\left(\mathrm{ml}^{-1}\right)$; then incubated at $28^{\circ} \mathrm{C}$ for 3 days. A ZR Genomic DNA II Kit was used for DNA isolation. Cells were then trypsinised off the surface of growth plates. The cell suspension was centrifuged at approximately $500 \mathrm{x}$ g for 5 minutes. The supernatant was removed and $500 \mu \mathrm{l}$ of Genomic Lysis Buffer added directly to the pellet. The pellet was re-suspended by vortexing. The mixture was then transferred to a Zymo-Spin-column in a collection tube and centrifuged at top speed (10 $000 \mathrm{rpm})$ for one minute.

The collection tube with the flow-through was discarded. Five hundred microliters of gDNA wash buffer were added to the spincolumn in a new collection tube and spinned at $10000 \mathrm{rpm}$ for one minute. The collection tube with the flow-through was discarded again. The spin-column was transferred to a clean micro-centrifuge tube and $35 \mu \mathrm{l}$ water were added to the spin-column. After one minute, to elute the DNA, the spin-column was centrifuged briefly at top speed. The DNA pellet was air-dried and immediately collected for storage at $<-20^{\circ} \mathrm{C}$ (Dodd et al., 2013).

Streptomyces DNA identification by $16 S$ rDNA sequencing. The $16 \mathrm{~S}$ target region was amplified using OneTaq Quickload 2 x Master Mix (NEB, Catalog No. M0486) with the primers (Table 1). The PCR products were run on a gel and extracted with a Zymoclean Gel DNA Recovery Kit (Zymo Research, Catalog No. D4001). The extracted fragments were sequenced in the forward and reverse directions (Nimagen, Brilliant Dye Terminator Cycle Sequencing Kit V3.3, BRD3 - 100/1000) and purified (Zymo Research, ZR-96 DNA Sequencing Clean up Kit, Catalog No. D4050). The purified fragments were analysed on the
ABI 3500XL Genetic Analyser (Applied Biosystems, Thermo-Fisher Scientific) for each reaction and sample. CLC Bio Man Workbench v7.6 was used to analyse the .ab1 files generated by the ABI 3500XL Genetic Analyser; and results were obtained by a Basic Local Alignment Search Tool (BLAST) search (NCBI) (Altschul et al., 1997).

Sequence processing and DNA-analysis. Sequences were aligned by hand in Bioedit (Hall, 1999). The final dataset consisted of 15 sequences for 15 species of the sequences were newly sequenced and 10 were obtained from GenBank, which had been part of earlier studies (Goredema et al., 2020). Evolutionary analyses were conducted in MEGA X (Kumar et al., 2018).

\section{RESULTS}

Isolation and morphological. Even though all Streptomyces isolates evidently formed an extensive network of primary vegetative mycelium branching, which differentiated into aerial mycelium that in turn produced spores, species specific variances in growth rates, mycelium colour, mycelia surface appearance, mycelia texture, pigmentation, opacity, spore shape and spore colour were observed. Streptomyces isolate characteristics were defined and further categorised in clusters containing strains with similar traits.

Cluster analysis strains from soil and compost. Twenty-seven Streptomyces isolates obtained from CUT Farm soils that suppressed growth of fungal pathogens in in-vitro tests, were clustered on the basis of their morphological characteristics. The isolates

TABLE 1. The $16 \mathrm{~S}$ rDNA primer sequences used in the study

\begin{tabular}{lll}
\hline Name of primer & Target & Sequence (5' to 3') \\
\hline $16 \mathrm{~S}-27 \mathrm{~F}$ & 16S rDNA sequence & AGAGTTTGATCMTGGCTCAG \\
$16 \mathrm{~S}-1492 \mathrm{R}$ & 16S rDNA sequence & CGGTTACCTTGTTACGACTT \\
\hline
\end{tabular}


were grouped into five distinct clusters (Fig. $1)$.

Cluster 1 comprised of Streptomyces isolates 1, 8, 9, 13, 14 and 20 (Fig. 1), characterised by whitish or greyish colonies, with smooth viscid surfaces. These Streptomyces produced yellow-opaque pigmentation, spores with globose and yellow colour (Table 1).

In vitro pathogen inhibition assay studies using the same Streptomyces spp. isolates showed that CUT-Streptomyces 20 in this cluster exhibited antimicrobial activity against $F$. oxysporum and P. italicum (Goredema et al., 2020).

Cluster 2 contained CUT-Streptomyces 2, 3, 4, 23, 25 and 26 (Fig. 1). Streptomyces isolates under cluster 2 were mostly fastgrowing grey and white colonies without pigmentation. They had viscid glistering surfaces, which were opaque (Table 2). Streptomyces spores in this class were mostly grey and globose. Four Streptomyces spp. in this cluster were classified as the best antibiotic producers; and possessing the best antagonistic activity against fungal pathogens in in vitro pathogen inhibition assays carried out in studies earlier on (Goredema et al., 2020). CUT-Streptomyces 23 and CUTStreptomyces 26 had the best $F$. oxysporum and $P$. italicum fungal pathogen antagonistic activity (Goredema et al., 2020). CUTStreptomyces 2, 4 and 25 also showed antimicrobial activity to selected fungal pathogens. Antimicrobial activity possessed by Streptomyces isolates in Cluster 2 show that their morphological characteristics can be used as criteria for selecting Streptomyces spp. with antimicrobial activity against fungal pathogens.

CUT-Streptomyces 5 and 21 were classified under Cluster 3. Streptomyces in this cluster were characterised by slow-growing grey and white glistering colonies, with whitish pigmentation. The Streptomyces appeared to be translucent and their surfaces viscid in texture. Spores of Streptomyces in Cluster 3

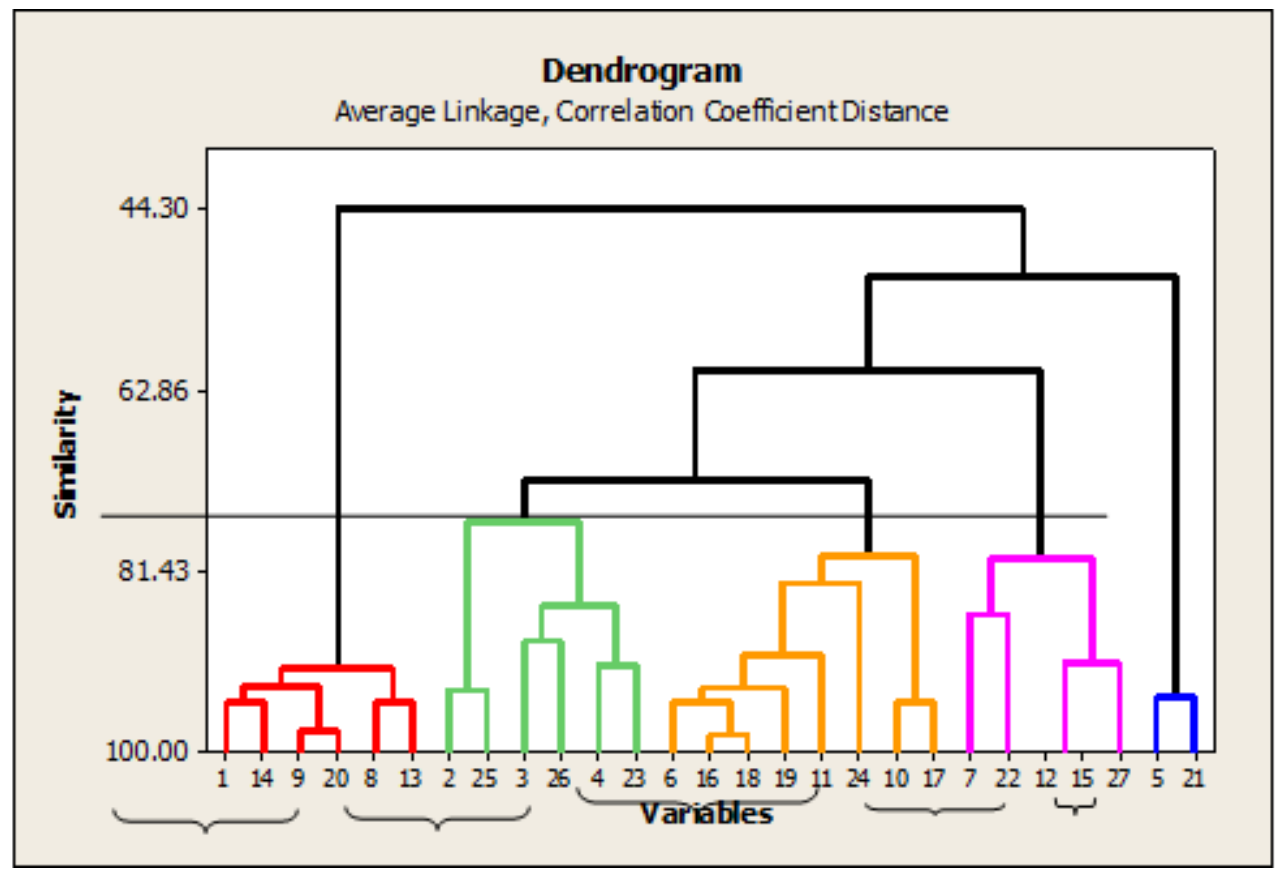

Figure 1. Relationship among 27 Streptomyces isolates that suppress growth of fungal pathogens classified based on morphological characteristics. The cut off point for the similarity coefficient was $80 \%$. 
TABLE 2. Morphological characterisation of Streptomyces isolates used in this study

\begin{tabular}{|c|c|c|c|c|c|c|c|c|c|c|}
\hline Isolate & $\begin{array}{l}\text { Growth } \\
\text { rate }\end{array}$ & $\begin{array}{l}\text { Grey } \\
\text { colour }\end{array}$ & $\begin{array}{l}\text { White } \\
\text { colour }\end{array}$ & $\begin{array}{l}\text { Brown } \\
\text { colour }\end{array}$ & Pigmentation & Surface & Opacity & Texture & Spore shape & Spore \\
\hline 1 & Moderate & Present & Present & Abstent & Yellow & Rough & Opaque & Viscid & Rod & Yellow \\
\hline 2 & Fast & Present & Present & Abstent & Colourless & Glistering & Translucent & Viscid & Globose & Grey \\
\hline 3 & Moderate & Present & Abstent & Abstent & Colourless & Glistering & Opaque & Viscid & Globose & Grey \\
\hline 4 & Fast & Abstent & Abstent & Present & Colourless & Glistering & Opaque & Viscid & Globose & Brown \\
\hline 5 & Slow & Present & Present & Abstent & whitish & Glistering & Translucent & Viscid & Globose & Grey \\
\hline 6 & Fast & Present & Present & Abstent & whitish & Smooth & Translucent & Viscid & Rod & White \\
\hline 7 & Moderate & Abstent & Present & Present & Colourless & Smooth & Translucent & Viscid & Rod & Grey \\
\hline 8 & Moderate & Present & Present & Present & Yellow & Rough & Opaque & Viscid & Globose & Yellow \\
\hline 9 & Moderate & Present & Present & Abstent & Yellow & Smooth & Opaque & Viscid & Globose & Yellow \\
\hline 10 & Fast & Present & Abstent & Present & Brown & Rough & Translucent & Viscid & Rod & Brown \\
\hline 11 & Fast & Present & Abstent & Abstent & Colourless & Rough & Translucent & Buttery & Globose & Brown \\
\hline 12 & Moderate & Abstent & Present & Abstent & Colourless & Smooth & Opaque & Buttery & Globose & Grey \\
\hline 13 & Moderate & Present & Present & Present & Yellow & Smooth & Opaque & Mucoid & Globose & Yellow \\
\hline 14 & Moderate & Present & Abstent & Abstent & Yellow & Rough & Opaque & Viscid & Globose & Yellow \\
\hline 15 & Moderate & Abstent & Present & Abstent & Colourless & Smooth & Opaque & Buttery & Globose & Grey \\
\hline 16 & Fast & Present & Present & Abstent & Colourless & Rough & Translucent & Viscid & Globose & White \\
\hline 17 & Fast & Abstent & Abstent & Present & Brown & Rough & Opaque & Viscid & Globose & Brown \\
\hline 18 & Fast & Present & Present & Abstent & Colourless & Smooth & Translucent & Viscid & Globose & White \\
\hline 19 & Fast & Present & Present & Abstent & Whitish & Smooth & Opaque & Buttery & Globose & White \\
\hline 20 & Moderate & Present & Present & Abstent & Yellow & Smooth & Opaque & Buttery & Globose & Yellow \\
\hline 21 & Slow & Present & Present & Abstent & Colourless & Glistering & Translucent & Viscid & Globose & Grey \\
\hline 22 & Slow & Abstent & Present & Present & Colourless & Smooth & Translucent & Buttery & Rod & Grey \\
\hline 23 & Moderate & Abstent & Abstent & Present & Colourless & Glistering & Opaque & Viscid & Globose & Brown \\
\hline 24 & Moderate & Abstent & Abstent & Present & Colourless & Smooth & Opaque & Viscid & Globose & White \\
\hline 25 & Fast & Present & Present & Abstent & Colourless & Rough & Opaque & Viscid & Globose & Yellow \\
\hline 26 & Moderate & Abstent & Present & Abstent & Colourless & Glistering & Opaque & Viscid & Globose & Grey \\
\hline 27 & Moderate & Abstent & Present & Present & Colourless & Smooth & Translucent & Buttery & Globose & Grey \\
\hline
\end{tabular}


were rod shaped and grey in colour (Table 2). Streptomyces spp. in this cluster showed no evidence of antagonistic or antimicrobial activity against $A$. flavus, $F$. oxysporum and P. italicum (Goredema et al., 2020).

Cluster 4 included CUT-Streptomyces 6, 10, 11, 16, 17, 18, 19 and 24 (Fig. 1). Streptomyces isolates in Cluster 4 were identified by their grey and or whitish fast-growing colonies with rough viscid surfaces. Streptomyces in this Cluster produced whitish or colourless translucent pigmentation, with spores of globose and brownish colour.
CUT-Streptomyces 7, 12, 15, 22 and 27 were grouped into Cluster 5 (Fig. 1). Streptomyces isolates in this cluster were unique by their moderate growth rates, whitebrownish smooth colonies, with colourless pigmentation. The Streptomyces colonies appeared to be translucent and their surfaces buttery in texture. Spores in this group were mostly rod shaped and grey in colour.

Table 3 summaries five Streptomyces spp. morphological clusters established using growth rates, colour, pigmentation, opacity, texture, spore shape and spore colour

TABLE 3. Morphological characteristics of the isolated Streptomyces spp. defined as major clusters according to Correlation Coefficient Distance and Average Linkage systems using Minitab

\begin{tabular}{|c|c|c|c|c|c|c|}
\hline \multirow[t]{2}{*}{ Growth rate } & & \multicolumn{5}{|c|}{ Clusters } \\
\hline & & 1 & 2 & 3 & 4 & 5 \\
\hline & 1 & - & - & + & - & - \\
\hline & 2 & + & - & - & - & + \\
\hline & 3 & - & + & - & + & - \\
\hline Grey colour & 4 & + & + & + & + & - \\
\hline White colour & 5 & + & + & + & + & + \\
\hline Brown colour & 6 & - & - & - & - & + \\
\hline \multirow[t]{4}{*}{ Pigmentation } & 7 & - & + & - & - & + \\
\hline & 8 & - & - & + & + & - \\
\hline & 9 & - & - & - & - & - \\
\hline & 10 & + & - & - & - & - \\
\hline \multirow[t]{3}{*}{ Surface } & 11 & + & - & - & - & + \\
\hline & 12 & - & - & - & + & - \\
\hline & 13 & - & + & + & - & - \\
\hline \multirow[t]{2}{*}{ Opacity } & 14 & + & + & - & - & - \\
\hline & 15 & - & - & + & + & + \\
\hline \multirow{3}{*}{ Texture } & 16 & - & - & - & - & - \\
\hline & 17 & + & + & + & + & - \\
\hline & 18 & - & - & - & - & + \\
\hline \multirow[t]{2}{*}{ Spore shape } & 19 & + & + & - & + & - \\
\hline & 20 & - & - & + & - & + \\
\hline \multirow[t]{4}{*}{ Spore colour } & 21 & + & - & - & - & - \\
\hline & 22 & - & - & - & + & - \\
\hline & 23 & - & + & + & + & + \\
\hline & 24 & - & - & - & - & - \\
\hline
\end{tabular}

$+=$ Positive,$-=$ Negative, $1=$ Slow, $2=$ Moderate, $3=$ Fast, $4=$ Grey colour, $5=$ White colour, $6=$ Brown colour, $7=$ Colourless, $8=$ Whitish, $9=$ Brown, $10=$ Yellow, $11=$ Smooth, $12=$ Rough, $13=$ Glistering, $14=$ Opaque, $15=$ Translucent, $16=$ Mucoid, $17=$ Viscid, $18=$ Buttery, $19=$ Globose, $20=$ Rod, $21=$ Yellow, $22=$ Brown, $23=$ White, $24=$ Orange 
similarity. This was done using the Correlation Coefficient Distance and Average Linkage systems by Minitab data analysis software. Sequences obtained from CUT-Streptomyces DNA identification by $16 \mathrm{~S}$ rDNA sequencing were subjected to BLAST. BLAST results showed that the selected Streptomyces isolates were similar to already discovered secondary metabolite producing Streptomyces strains (Table 4).

BLAST findings showed that, of the five sequenced isolates, four CUT-Streptomyces isolates were from the genus Streptomyces; while one strain was identified as Stenotrophomonas maltophilia (Table 4).

Phylogenic analysis. In the course of characterising twenty-seven novel antibioticproducing Streptomyces isolated from Chinhoyi University of Technology Farm soils and composts, five Streptomyces clusters were developed (Fig. 1). One Streptomyces isolate was randomly selected from each of the five morphological clusters and the 16S rDNA sequenced were queried against Genbank sequences. Similar sequences which appeared to be highly similar to CUT-Streptomyces $16 \mathrm{~S}$ rDNA sequences were retrieved. The basis of their selection was identity similarity (Table 4). BLASTN results showed that the selected Streptomyces isolates were similar to already discovered secondary metabolite producing Streptomyces strains (Table 4).

The evolutionary history was inferred by using the Maximum Likelihood method and Jukes-Cantor model. The tree with the highest $\log$ likelihood (-6058.89) is shown in Figure 2. The percentage of trees in which the associated taxa clustered together is shown next to the branches. Initial tree(s) for the heuristic search were obtained automatically by applying Neighbor-Join and BioNJ algorithms to a matrix of pairwise distances, estimated using the Maximum Composite Likelihood (MCL) approach, and then selecting the topology with superior log likelihood value. Codon positions included were

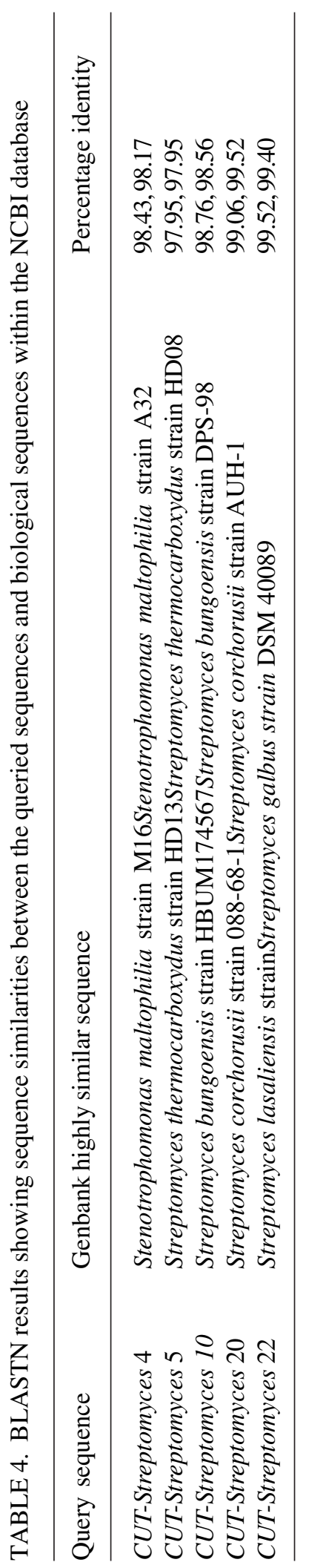




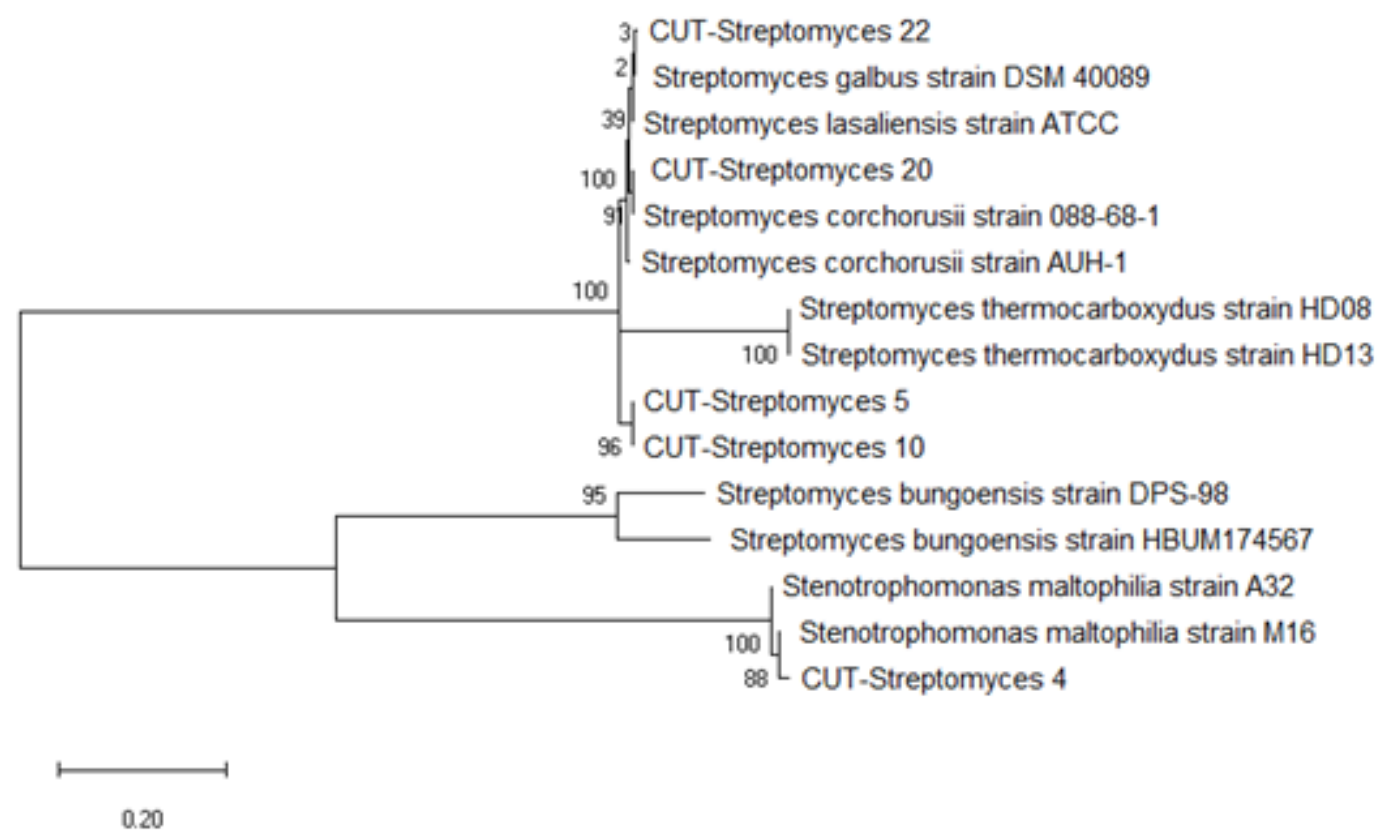

Figure 2. Dendogram showing evolutionary relationships between isolated CUT-Streptomyces and bacterium from the Genbank. The tree is drawn to scale, with branch lengths measured in the number of substitutions per site.

1st+2nd+3rd+Noncoding. There were a total of 1478 positions in the final dataset.

\section{DISCUSSION}

The five representative isolates that were characterised were CUT-Streptomyces 4, 5, 10, 20 and 22 found in this study belongs to the genus Streptomyces and was confirmed by the identification method of Atalan et al. (2000) (method for identification of Streptomyces species and subspecies). CUT-Streptomyces 5 isolate portrayed a sequence similarity to that of $S$. thermocarboxydus species from Jacob et al. (2008). Streptomyces thermocarboxydus has strong antagonistic activity against pathogenic microbes, enabled by its ability to degrade living cells of pathogenic microorganisms such as fungi and bacteria; thus biologically protecting plants (Kim et al., 1998). Furthermore, this strain has the ability to secrete enzymes that take part in the breakdown and mineralisation of plant, animal and other naturally-occurring organic substances; and in so doing, release important nutrients for plant growth and development (Jacob et al., 2008).

CUT-Streptomyces 20, an isolate that showed high antagonistic activity (Goredema et al., 2020) to F. oxysporum, was also found to belong to genus Streptomyces. The isolate showed sequence resemblance to that of $S$. corchorusii. El-Shanshoury et al. (1996) showed that supplementation of chemical control agents with $S$. corchorusii and $S$. mutabilis increased their inhibitory effects against $P$. solanacearum and $F$. oxysporum. Adinarayana et al. (2006) isolated a bioactive Streptomyces from marine sediment samples collected from the Bay of Bengal, India. Taxonomically, the isolate was related to $S$. corchorusii. It also demonstrated in vitro potent cytotoxic activity and antibacterial activity against Gram-positive and Gramnegative bacteria. Furthermore, Tamreihao et al. (2016) found $S$. corchorusii to be affirmative for the production of fungal cell wall degrading enzymes such as chitinase, $\beta$-1,3-glucanase, 
$\beta$-1,4-glucanase, lipases and proteases. This evidence confirms the antagonistic activity of CUT-Streptomyces 20 against pathogenic microbes.

Isolate 10 , showing antimicrobial activity against $F$. oxysporum growth by depriving the fungus of nutrients and space, was shown to belong to the genus Streptomyces. Molecular identification of the isolate showed its likeness to $S$. bungoensis. Work by Atta in 2010 in screening actinomycetes for the production of bioactive substances, led to the discovery of Streptomyces spp. AZ-Z710 strain with 88\% similarity with S. bungoensis.

Similar to CUT-Streptomyces 10, AZ-Z710 elicited the ability to produce broad-spectrum antibiotics. Such antibiotic compounds inhibited the growth of pathogenic microbes. Cheng (2013) isolated and selected isolate MJM2077 for its strong anti-Staphylococcus aureus activity. Based on the analysis of its 16S rDNA, isolate MJM2077 too labelled as S. bungoensis. This evidence supports findings of the ability of CUT-Streptomyces 10 in possessing antimicrobial activity against fungal pathogens because of its similarity to $S$. bungoensis.

Through morphological and molecular characteristics, CUT-Streptomyces 22, an isolate that elicited potential antimicrobial activity against $P$. italicum and $F$. oxysporum was also found belonging to the genus Streptomyces. CUT-Streptomyces 22 exhibited a sequence close to $S$. lasaliensis. Kinashi (1987), identified giant linear plasmids in $S$. lasaliensis which code for antibiotic biosynthesis genes. These were confirmed by Smaoui et al. (2012) to be genes for methylenomycin biosynthesis. This is evidence that CUT-Streptomyces 22 had the ability to elicit antimicrobial activity possibly be attributed to methylenomycin as shown in $S$. lasaliensis.

It is clear from the present study that $C U T-$ Streptomyces 5, 10, 20 and 22 showed antagonistic activity against $F$. oxysporum, $P$. italicum and A. flavus. These isolates were also shown to belong to genus Streptomyces and were taxonomically related to already known; Streptomyces strains possessing antimicrobial activity against plant pathogens. Results of this study provide strong backing to earlier studies which have already proved Actinomyces to be one of the principal bacteria present in soil and also that Streptomyces spp. are a novel source of secondary metabolites that can be used for the control of plant diseases.

\section{ACKNOWLEDGEMENT}

This research was funded by Chinhoyi University of Technology, through the Vice Chancellors Excellence Award. We thank the Department Plant Pathology, University of Zimbabwe for providing laboratory facilities and materials for this work.

\section{REFERENCES}

Adinarayana, G., Venkateshan, M.R., Bapiraju, V.V. S.N.K., Sujatha, P., Premkumar, J., Ellaiah, P. and Zeeck, A. 2006. Cytotoxic compounds from the marine actinobacterium Streptomyces corchorusii AUBN 1/7. Russian Journal of Bioorganic Chemistry 32(3):295-300.

Allen, C.D., Macalady, A.K., Chenchouni, H., Bachelet, D., McDowell, N., Vennetier, M. and Gonzalez, P. 2010. A global overview of drought and heat-induced tree mortality reveals emerging climate change risks for forests. Forest Ecology and Management 259(4):660-684.

Ambarwati, A., Sembiring, L. and Soegihardjo, C.J. 2012. Antibiotic produced by Streptomycetes associated with rhizosphere of purple nut sedge (Cyperus rotundus L.) in Surakarta, Indonesia. African Journal of Microbiology Research 6(1):52-57.

Atta, H.M., Bayoumi, R., El-Sehrawi, M., Aboshady, A. and Al-Humiany, A. 2010. Biotechnological application for producing some antimicrobial agents by actinomycetes isolates from Al-khurmah Governorate. Eur J Appl Sci, 2:98-107. 
Altschul, S.F., Madden, T.L., Schäffer, A. A., Zhang, J., Zhang, Z., Miller, W. and Lipman, D.J. 1997. Gapped BLAST and PSI-BLAST: a new generation of protein database search programs. Nucleic Acids Research 25(17):3389-3402.

Berdy, J. 2005. Bioactive microbial metabolites. The Journal of antibiotics 58(1):1.

Bhat, R.G. and Subbarao, K.V. 1999. Host range specificity in Verticillium dahliae. Phytopathology 89(12):1218-1225.

Compant, S., Duffy, B., Nowak, J., Clément, C. and Barka, E.A. 2005. Use of plant growth-promoting bacteria for biocontrol of plant diseases: Principles, mechanisms of action, and future prospects. Applied and Environmental Microbiology 71(9): 4951-4959.

Cheng, J., Jin, Y.Y., Yang, S.H. and Suh, J.W. 2013. Isolation and characterization of antimethicillinresistant Staphylococcus aureus/ vancomycinresistant Enterococcus compound from Streptomyces bungoensis MJM 2077. Journal of the Korean Society for Applied Biological Chemistry 56(1): 107-111.

Dodd, A., Swanevelder, D., Featherston, J. and Rumbold, K. 2013. Draft genome sequence of Streptomyces albulus strain CCRC 11814, an å-poly-l-lysine-producing actinomycete. Genome Announcement 1(5):e00696-13.

Doumbou, C.L., Hamby Salove, M.K., Crawford, D.L. and Beaulieu, C. 2001. Actinomycetes, promising tools to control plant diseases and to promote plant growth. Phytoprotection 82(3):85-102.

El-Shanshoury, A.E.R.R., El-Sououd, S.M.A., Awadalla, O.A. and El-Bandy, N.B. 1996. Effects of Streptomyces corchorusii, Streptomyces mutabilis, pendimethalin and metribuzin on the control of bacterial and Fusarium wilt of tomato. Canadian Journal of Botany 74(7):1016-1022.

Flärdh, K. and Buttner, M.J. 2009. Streptomyces morphogenetics: Dissecting differentiation in a filamentous bacterium. Nature Reviews Microbiology 7(1):36.
Gontang, E.A., Fenical, W. and Jensen, P.R. 2007. Phylogenetic diversity of grampositive bacteria cultured from marine sediments. Applied and Environmental Microbiology 73(10):3272-3282.

Goredema, N., Ndowora, T., Shoko, R. and Ngadze, E. 2020. In vitro suppression of pathogenic fungi by Streptomyces spp. African Crop Science Journal 28(2):141149.

Junaid, J.M., Dar, N.A., Bhat, T.A., Bhat, A.H. and Bhat, M.A. 2013. Commercial biocontrol agents and their mechanism of action in the management of plant pathogens. International Journal of Modern Plant \& Animal Sciences 1(2):39-57.

Hall, T.A. 1999. BioEdit: A user-friendly biological sequence alignment editor and analysis program for Windows 95/98/NT. In: Nucleic acids symposium series. [London]: Information Retrieval Ltd., c1979-c2000 41(41):95-98)

Ikeda, H., Ishikawa, J., Hanamoto, A., Shinose, M., Kikuchi, H., Shiba, T. and Ômura, S. 2003. Complete genome sequence and comparative analysis of the industrial microorganism Streptomyces avermitilis. Nature Biotechnology 21(5): 526.

Jacob, N., Poorna, C.A. and Prema, P. 2008. Purification and partial characterization of polygalacturonase from Streptomyces lydicus. Bioresource Technology 99(14): 6697-6701.

Jacob, S. and Sudini, H.K. 2016. Indirect plant growth promotion in grain legumes: Role of actinobacteria. pp. 17-32. In: Plant growth promoting actinobacteria. Springer, Singapore.

Jukes, T.H. and Cantor, C.R. 1969. Evolution of protein molecules. Mammalian Protein Metabolism 3(21):132.

Jüttner, F. and Watson, S.B. 2007. Biochemical and ecological control of geosmin and 2methylisoborneol in source waters. Applied and Environmental Microbiology 73(14): 4395-4406. 
Kavitha, A., Prabhakar, P., Vijayalakshmi, M. and Venkateswarlu, Y. 2010. Purification and biological evaluation of the metabolites produced by Streptomyces sp. TK-VL_333. Research in Microbiology 161(5):335-345.

Kieser, T., Bibb, M.J., Buttner, M.J., Chater, K.F. and Hopwood, D.A. 2000. Practical Streptomyces. Genetics 59.

Kim, S.B., Falconer, C., Williams, E. and Goodfellow, M. 1998. Streptomyces thermocarboxydovorans sp. nov. and Streptomyces thermocarboxydus sp. nov., two moderately thermophilic carboxydotrophic species from soil. International Journal of Systematic and Evolutionary Microbiology 48(1):59-68.

Kinashi, H., Shimaji, M. and Sakai, A. 1987. Giant linear plasmids in Streptomyces which code for antibiotic biosynthesis genes. Nature 328(6129):454.

Kumar, S., Stecher, G., Li, M., Knyaz, C. and Tamura, K. 2018. MEGA X: Molecular evolutionary genetics analysis across computing platforms. Molecular Biology and Evolution 35(6):1547-1549.

Lewin, G.R., Carlos, C., Chevrette, M.G., Horn, H.A., McDonald, B.R., Stankey, R. J. and Currie, C.R. 2016. Evolution and ecology of Actinobacteria and their bioenergy applications. Annual Review of Microbiology 70:235-254.

Ludwig, W., Euzéby, J., Schumann, P., Busse, H.J., Trujillo, M.E., Kämpfer, P. and Whitman, W.B. 2012. Road map of the phylum Actinobacteria. pp. 1-28. In: Bergey's manual ${ }^{\circledR}$ of systematic bacteriology. Springer, New York, USA.

Smaoui, S., Mathieu, F., Elleuch, L., Coppel, Y., Merlina, G., Karray-Rebai, I. and Mellouli, L. 2012. Taxonomy, purification and chemical characterization of four bioactive compounds from new Streptomyces sp. TN256 strain. World Journal of Microbiology and Biotechnology 28(3): 793-804.

Strange, R.N. and Scott, P.R. 2005. Plant disease: A threat to global food security. Annual Review of Phytopathology 43:83116.

Tamreihao, K., Ningthoujam, D.S., Nimaichand, S., Singh, E.S., Reena, P., Singh, S.H. and Nongthomba, U. 2016. Biocontrol and plant growth promoting activities of a Streptomyces corchorusii strain UCR3-16 and preparation of powder formulation for application as biofertilizer agents for rice plant. Microbiological Research 192:260-270.

Waksman, S.A. and Henrici, A.T. 1943. The nomenclature and classification of the actinomycetes. Journal of Bacteriology 46(4):337.

Willemse, J., Borst, J.W., de Waal, E., Bisseling, T. and van Wezel, G.P. 2011. Positive control of cell division: FtsZ is recruited by $\mathrm{SsgB}$ during sporulation of Streptomyces. Genes \& Development 25(1):89-99. 